\title{
ANALISIS POTENSI PENERAPAN SISTEM RAINWATER HARVESTING PADA KAMPUS I UNIVERSITAS TARUMANAGARA
}

\author{
Jonathan Putra', Wati A. Pranoto2 \\ ${ }^{1}$ Program Studi Sarjana Teknik Sipil, Universitas Tarumanagara, Jl. Letjen S. Parman No.1 Jakarta \\ Email: jonathanputra.tjung@gmail.com \\ ${ }^{2}$ Program Studi Sarjana Teknik Sipil, Universitas Tarumanagara, Jl. Letjen S. Parman No.1 Jakarta \\ Email: watip@ft.untar.ac.id
}

\begin{abstract}
ABSTRAK
Indonesia merupakan wilayah dengan curah hujan yang tinggi dan cenderung terdistribusi secara merata sepanjang tahun tanpa ada perbedaan yang mencolok antara musim hujan dan kemarau. Potensi sumber air bersih alami ini, apabila di manfaatkan dalam bentuk sistem Rainwater Harvesting di lokasi Kampus I Universitas Tarumanagara dapat menghemat air bersih per harinya sekitar 27,0497\% pada hari hujan dari kebutuhan air harian menurut perhitungan SNI 03-7065-2005. Sedangkan menurut data tagihan bulanan air, sistem Rainwater Harvesting apabila diterapkan dapat menghemat air hingga 87,1169\% pada hari hujan. Biaya air PAM yang dapat dihemat per tahun sebesar Rp 234.195.703,-. Kemudian bak penampung yang dibutuhkan untuk menampung air hujan total sebesar $168,2924 \mathrm{~m}^{3}$.
\end{abstract}

Kata Kunci : rainwater harvesting, penghematan air

\section{PENDAHULUAN}

Air merupakan kebutuhan yang sangat penting dalam kehidupan manusia. Namun sangat disayangkan, kebutuhan air bersih seringkali tidak memenuhi jumlah yang dibutuhkan manusia sehingga seringkali manusia kekurangan air bersih. Salah satu alternatif yang dapat digunakan untuk memenuhi kebutuhan air bersih adalah Rainwater Harvesting (RWH). RWH merupakan kegiatan menampung air hujan secara lokal dan menyimpannya melalui berbagai teknologi untuk penggunaan masa depan untuk memenuhi tuntutan konsumsi manusia atau kegiatan manusia (www.kelair.bppt.go.id). Pada sebuah penelitian di Hotel Novotel Yogyakarta yang dilakukan oleh mahasiswa UGM pada tahun 2014, rata-rata air hujan yang dapat ditampung dalam satu bulan yaitu 478.820 liter dan dalam satu tahun dapat terkumpul sebesar 5.745.809 liter. Pada musim hujan, air hujan pada Hotel Novotel dapat memasok hingga $21 \%$ dari total kebutuhan air bersih dalam satu bulan. Rata-rata konsumsi air yang dapat ditangani oleh air hujan dalam setahun adalah $8,6 \%$. Oleh sebab itu, penelitian ini dilakukan untuk mengetahui berapa rata-rata air hujan yang dapat ditampung dalam satu hari di Kampus 1 Universitas Tarumanagara dengan tujuan untuk memenuhi kebutuhan air bersih di kampus.

\section{METODOLOGI PENELITIAN}

\section{Alur penelitian}

Penelitian dilaksanakan dengan mengacu pada Gambar 1 


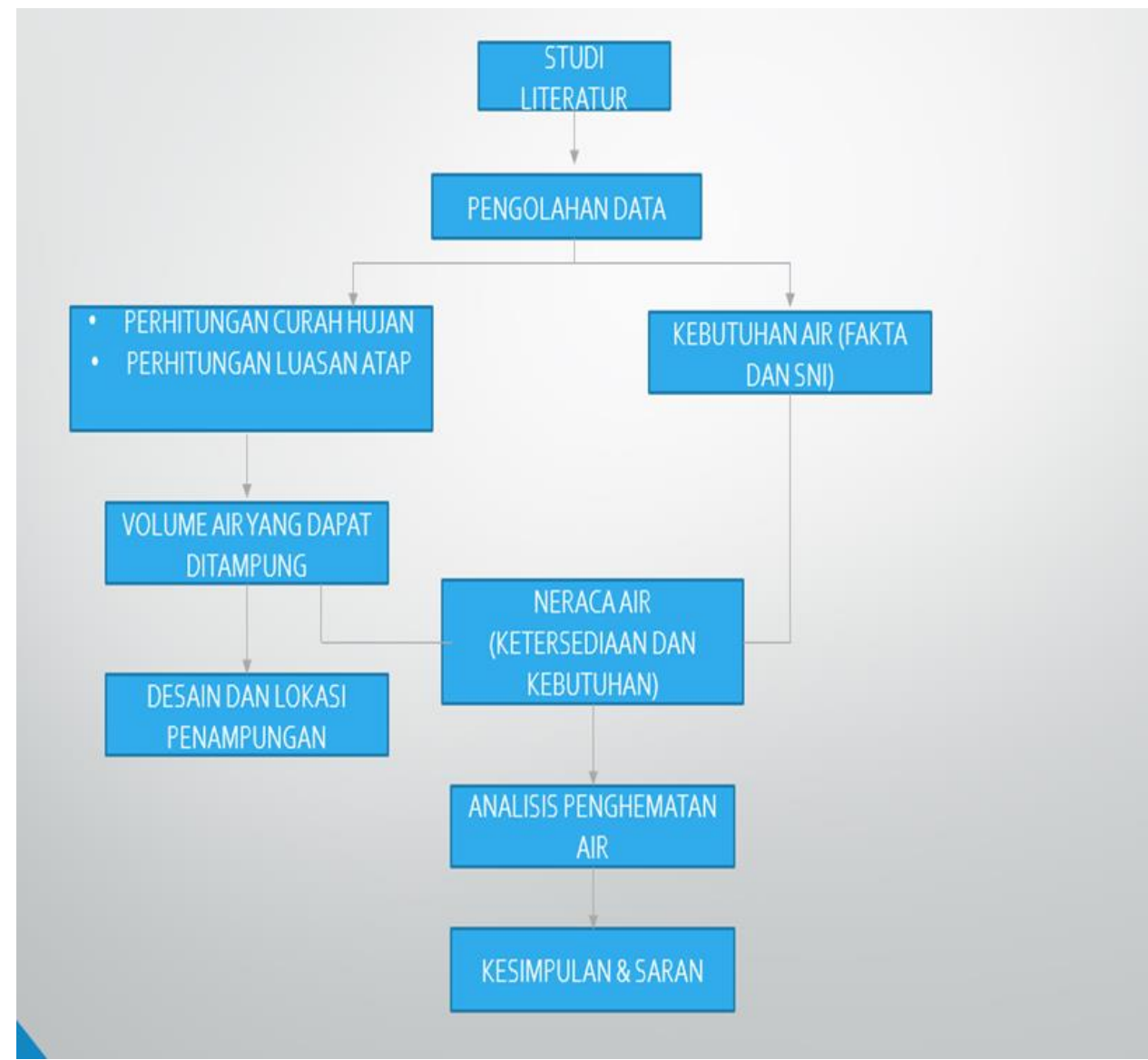

Gambar 1. Diagram alir penelitian

\section{ANALISIS DAN PEMBAHASAN}

\section{Hasil analisis jarak antara stasiun hujan kemayoran dengan kampus I}

Berikut jarak antara Stasiun Meteorologi Kemayoran, Stasiun Klimatologi Tangerang Selatan, Stasiun Meteorologi Maritim Tanjung Priok, dan Stasiun Meteorologi Soekarno Hatta dengan Kampus I Universitas Tarumanagara yang berlokasi di Jalan Letjen S. Parman No.1 seperti pada gambar 2, gambar 3, gambar 4, dan gambar 5

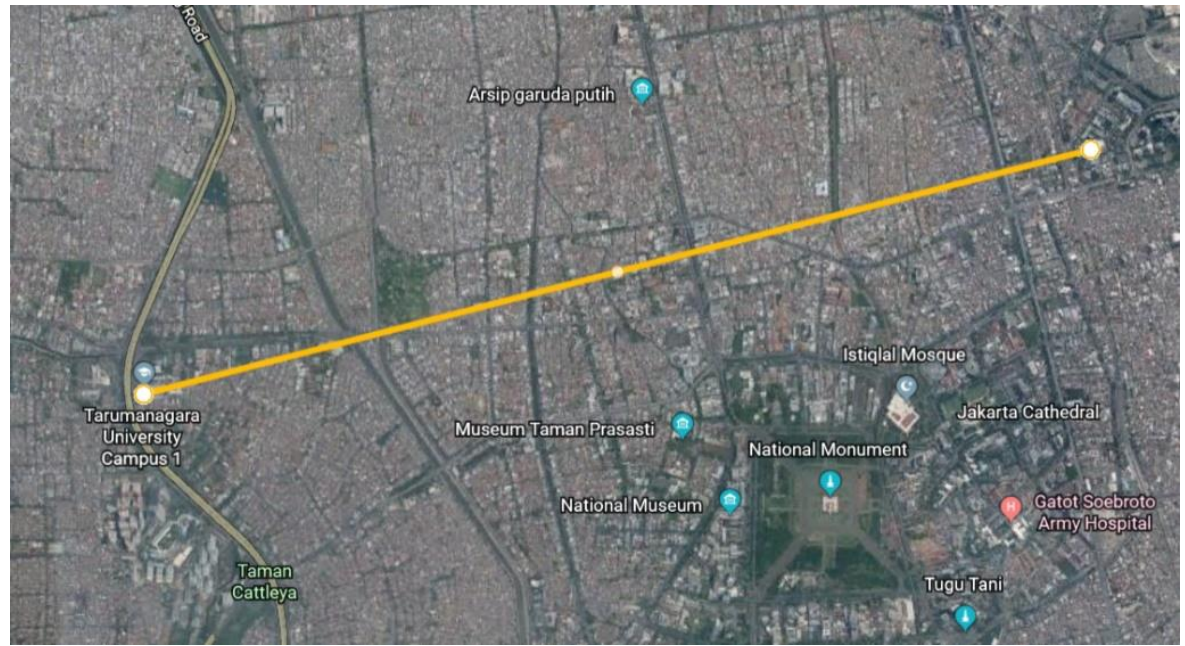

Gambar 2. Jarak antara Kampus 1 Universitas Tarumanagara dengan Stasiun Meteorologi Kemayoran sejauh 6,005 meter (Sumber: Google Earth) 


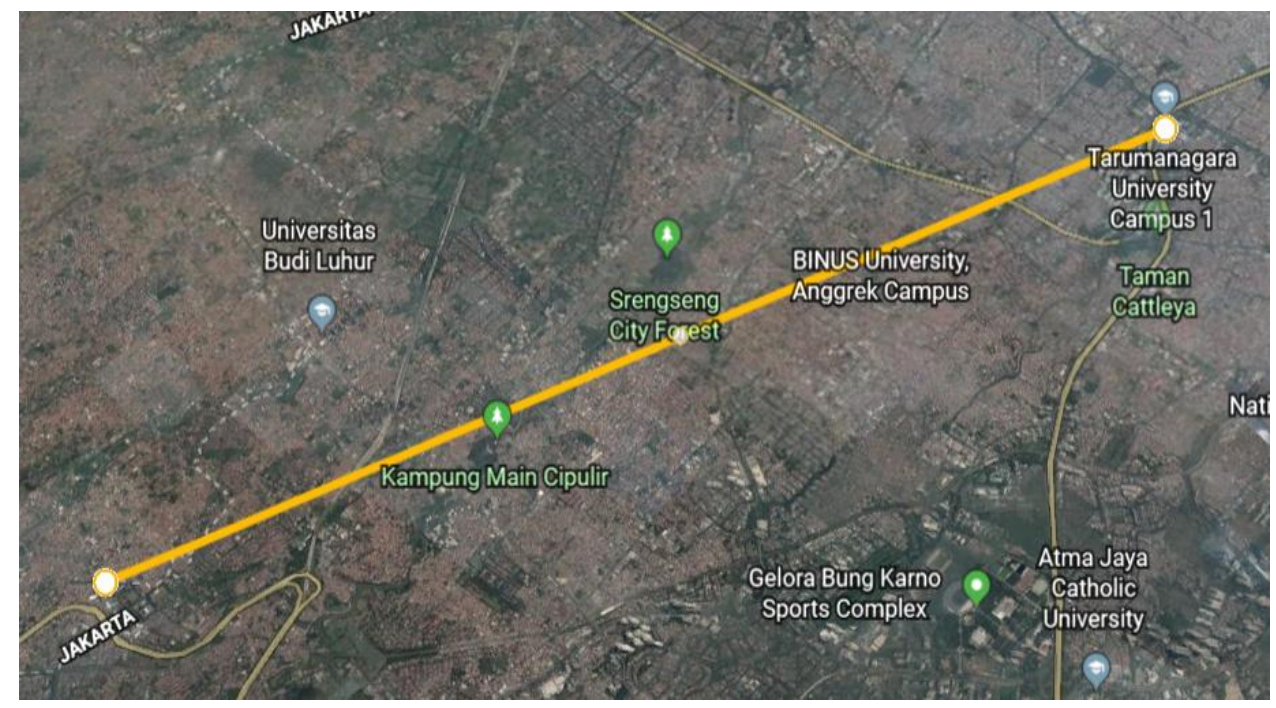

Gambar 3. Jarak antara Kampus 1 Universitas Tarumanagara dengan Stasiun Klimatologi Tangerang Selatan sejauh 10,986 meter (Sumber: Google Earth)

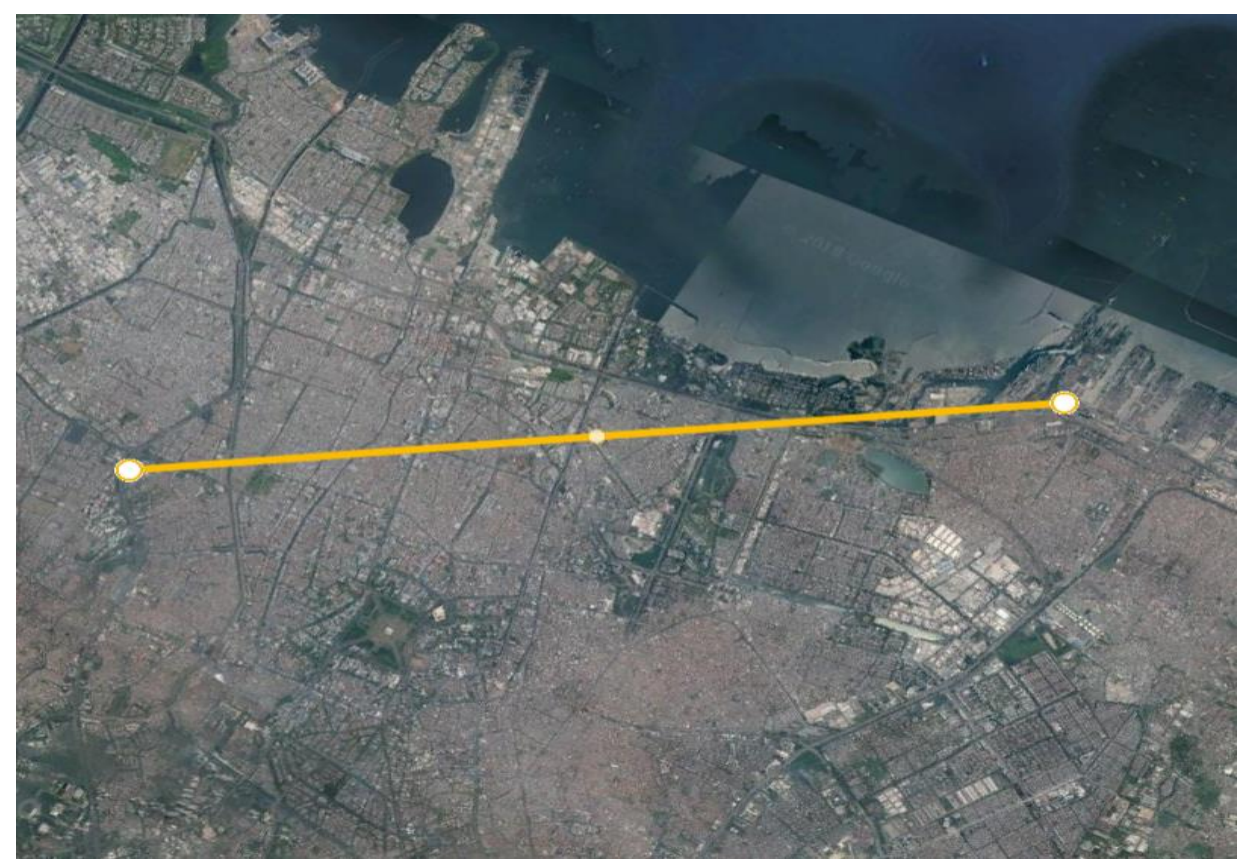

Gambar 4. Jarak antara Kampus I dengan Stasiun Meteorologi Maritim Tanjung Priok sejauh 12,240 meter (Sumber: Google Earth) 


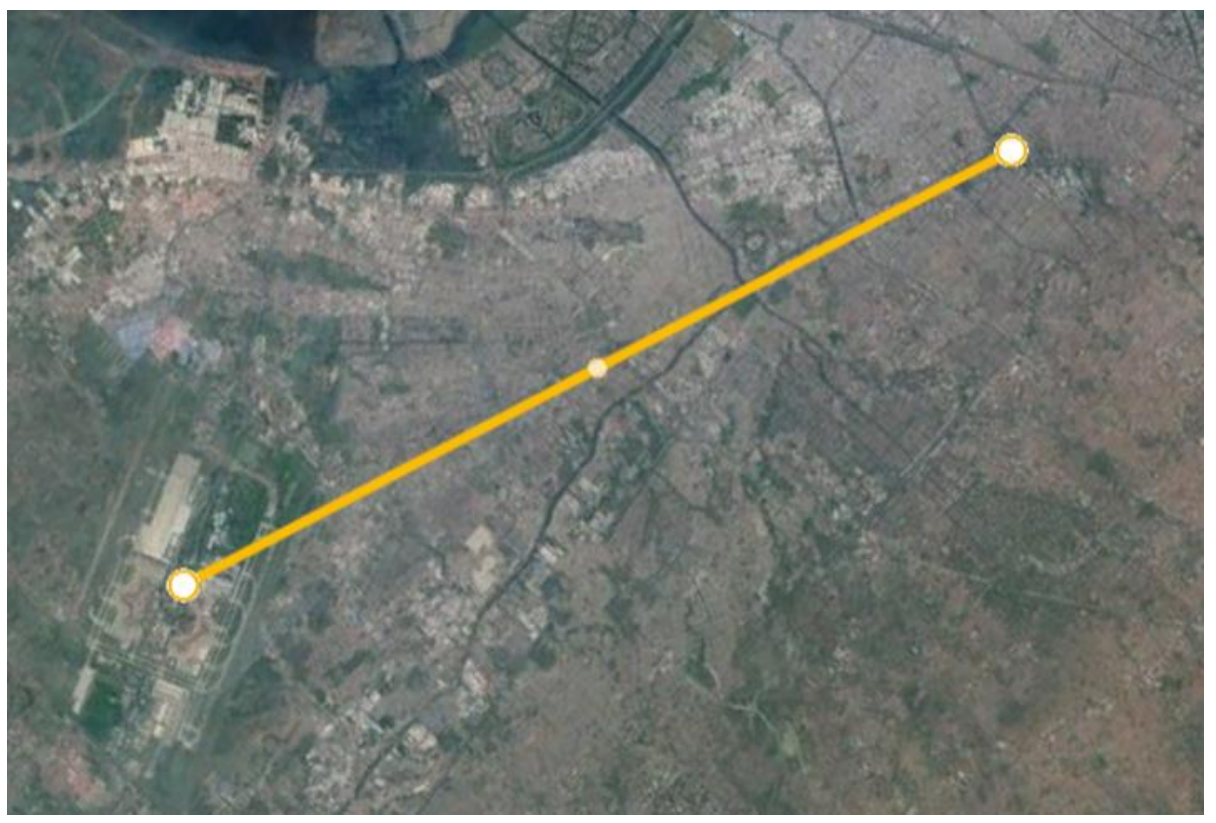

Gambar 5. Jarak antara Kampus I dengan Stasiun Meteorologi Soekarno Hatta Sejauh 15,210 meter (Sumber: Google Earth)

Dari hasil survey Google Earth, didapat jarak antara Kampus I dengan stasiun hujan antara lain:

- Stasiun Meteorologi Kemayoran

- $\quad$ Stasiun Klimatologi Tangerang Selatan

- $\quad$ Stasiun Meteorologi Maritim Tanjung Priok

- $\quad$ Stasiun Meteorologi Soekarno Hatta
: 6005 meter

: 10986 meter

: 12240 meter

: 15210 meter

Maka stasiun hujan dengan jarak terdekat dengan Kampus I adalah Stasiun Meteorologi Kemayoran.

\section{Hasil analisis curah hujan harian rata-rata}

Data curah hujan harian rata-rata yang digunakan adalah data dari Stasiun Meteorologi Kemayoran, karena lokasinya berada paling dekat dengan Kampus I. Perhitungan seperti pada tabel 1 di bawah.

Tabel 1. Curah Hujan Harian Rata-Rata Stasiun Meteorologi Kemayoran

\begin{tabular}{ccccl}
\hline Tahun & $\begin{array}{c}\text { Jumlah } \\
\text { Curah } \\
\text { Hujan } \\
(\mathbf{m m})\end{array}$ & $\begin{array}{c}\text { Jumlah } \\
\text { Hari } \\
\text { Hujan }\end{array}$ & $\begin{array}{c}\text { Curah } \\
\text { Hujan } \\
\text { Harian } \\
\text { Rata- } \\
\text { Rata } \\
(\mathbf{m m})\end{array}$ & Bulan Hujan Dominan \\
\hline 2007 & 2353,9 & 142 & 16,577 & Februari dan Desember \\
\hline 2008 & 1909,2 & 130 & 14,686 & Februari \\
\hline 2009 & 1973 & 123 & 16,041 & Januari \\
\hline 2010 & 2395 & 183 & 13,087 & Januari dan Oktober \\
\hline 2011 & 1274,1 & 132 & 9,652 & Februari \\
\hline
\end{tabular}




\begin{tabular}{ccccl}
2012 & 1488,2 & 122 & 12,198 & November dan Desember \\
\hline 2013 & 2528,1 & 169 & 14,959 & Januari dan Desember \\
\hline 2014 & 2837,1 & 141 & 20,121 & Januari dan Februari \\
\hline 2015 & 2086,7 & 108 & 19,321 & Januari dan Februari \\
\hline 2016 & 2711,5 & 181 & 14,981 & Februari \\
\hline 2017 & 2152,1 & 132 & 16,304 & Februari \\
\hline \multicolumn{2}{c}{ Total } & $\mathbf{1 5 6 3}$ & $\mathbf{1 6 7 , 9 2 8}$ & \\
Rata-Rata & $\mathbf{1 4 2 , 0 9}$ & $\mathbf{1 5 , 2 6 6}$ & \\
\hline
\end{tabular}

Contoh Perhitungan:

$$
\begin{aligned}
\text { Rata }- \text { rata } & =\frac{\sum \text { Curah Hujan Harian Rata-Rata }}{\text { Jumlah Data }} \\
& =\frac{167,928}{11} \\
& =15,266 \mathrm{~mm}
\end{aligned}
$$

\section{Hasil perhitungan dengan metode gumbel}

Tabel 2. Perhitungan Metode Gumbel untuk Stasiun Meteorologi Kemayoran

\begin{tabular}{lccccc}
\hline \multicolumn{1}{c}{ Nama Stasiun } & Tahun & $\begin{array}{c}\text { Curah Hujan } \\
\text { Maksimum } \\
(\mathbf{X i})\end{array}$ & $(\mathbf{X i - X})^{\wedge} \mathbf{2}$ & $(\mathbf{X i - X})^{\wedge} \mathbf{3}$ & $\mathbf{( X i - X )}^{\wedge} \mathbf{4}$ \\
\hline Stasiun Meteorologi Kemayoran & 2007 & 234,7 & 5176,148 & 372400,35 & 26792512,6 \\
\hline Stasiun Meteorologi Kemayoran & 2008 & 192,7 & 896,7302 & 26852,995 & 804125,138 \\
\hline Stasiun Meteorologi Kemayoran & 2009 & 122,5 & 1620,428 & 65229,61 & 2625788,3 \\
\hline Stasiun Meteorologi Kemayoran & 2010 & 93 & 4865,697 & 339404,46 & 23675003,5 \\
\hline Stasiun Meteorologi Kemayoran & 2011 & 119,2 & 1896,998 & 82622,904 & 3598603,04 \\
\hline Stasiun Meteorologi Kemayoran & 2012 & 105,2 & 3312,526 & 190650,91 & 10972826,5 \\
\hline Stasiun Meteorologi Kemayoran & 2013 & 193,4 & 939,1439 & 28780,491 & 881991,235 \\
\hline Stasiun Meteorologi Kemayoran & 2014 & 147,9 & 220,6575 & 3277,7672 & 48689,7414 \\
\hline Stasiun Meteorologi Kemayoran & 2015 & 277,5 & 13166,52 & 1510798,2 & 173357232 \\
\hline Stasiun Meteorologi Kemayoran & 2016 & 124,5 & 1463,41 & 55982,094 & 2141569,55 \\
\hline Stasiun Meteorologi Kemayoran & 2017 & 179,7 & 287,1484 & 4865,8607 & 82454,2207 \\
\hline & Jumlah & 1790,3 & 33845,41 & 2680865,7 & 244980795 \\
\hline Rata-rata & 162,7545455 & & & \\
\hline
\end{tabular}




\section{Hasil perhitungan dengan metode log pearson III}

Tabel 3. Perhitungan Metode Log Pearson III untuk Stasiun Meteorologi Kemayoran

\begin{tabular}{|c|c|c|c|c|c|}
\hline Nama Stasiun & Tahun & $\begin{array}{c}\text { Curah } \\
\text { Hujan } \\
\text { Maksimum } \\
\text { (Xi) }\end{array}$ & $\log X \mathbf{X}$ & $\begin{array}{c}(\mathrm{Log} \\
\mathrm{Xi}-\mathbf{L o g} \\
\mathrm{X})^{\wedge} \mathbf{2}\end{array}$ & $\begin{array}{c}(\log X \mathbf{X}- \\
\log \\
\mathbf{X})^{\wedge} \mathbf{3}\end{array}$ \\
\hline Stasiun Meteorologi Kemayoran & 2007 & 234,7 & 2,37051 & 0,03359 & 0,00616 \\
\hline Stasiun Meteorologi Kemayoran & 2008 & 192,7 & 2,28488 & 0,00953 & 0,00093 \\
\hline Stasiun Meteorologi Kemayoran & 2009 & 122,5 & 2,08814 & 0,00982 & 0,00097 \\
\hline Stasiun Meteorologi Kemayoran & 2010 & 93 & 1,96848 & 0,04786 & 0,01047 \\
\hline Stasiun Meteorologi Kemayoran & 2011 & 119,2 & 2,07628 & 0,01231 & 0,00137 \\
\hline Stasiun Meteorologi Kemayoran & 2012 & 105,2 & 2,02202 & 0,02730 & 0,00451 \\
\hline Stasiun Meteorologi Kemayoran & 2013 & 193,4 & 2,28646 & 0,00984 & 0,00098 \\
\hline Stasiun Meteorologi Kemayoran & 2014 & 147,9 & 2,16997 & 0,00030 & 0,00001 \\
\hline Stasiun Meteorologi Kemayoran & 2015 & 277,5 & 2,44326 & 0,06554 & 0,01678 \\
\hline Stasiun Meteorologi Kemayoran & 2016 & 124,5 & 2,09517 & 0,00848 & 0,00078 \\
\hline \multirow[t]{4}{*}{ Stasiun Meteorologi Kemayoran } & 2017 & 179,7 & 2,25455 & 0,00453 & 0,00030 \\
\hline & Jumlah & 1790,3 & 24,05971 & 0,22911 & 0,00704 \\
\hline & Rata-rata & 162,7545455 & 2,18725 & 0,02083 & 0,00064 \\
\hline & $\begin{array}{c}\text { Standar } \\
\text { Deviasi (S) }\end{array}$ & 0,15136 & & & \\
\hline
\end{tabular}

\section{Hasil perhitungan kebutuhan air gedung menurut SNI 03-7065-2005}

Berdasarkan data yang diperoleh, maka jumlah keseluruhan dosen dan mahasiswa pada tahun ajaran 2017/2018 adalah 259 dosen dan 7518 mahasiswa. Menurut SNI 03-7065-2005, kebutuhan air untuk gedung SMU/SMK dan lebih tinggi adalah minimal 80 Liter/siswa/hari. Maka kebutuhan air pada kampus I adalah 622.160 Liter per hari dan kebutuhan bulanannya adalah 12.443.200 Liter.

\section{Kebutuhan air gedung berdasarkan data tagihan air PAM}

Tabel 4. Data Pemakaian dan Tagihan Air Kampus I

\begin{tabular}{ccccc}
\hline No & Tahun & Bulan & Pemakaian $\left(\mathbf{m}^{\mathbf{3}}\right)$ & $\begin{array}{c}\text { Tagihan } \\
(\mathbf{R p})\end{array}$ \\
\hline 1 & 2016 & Januari & 2587 & 25.352 .600 \\
\hline 2 & 2016 & Februari & 2729 & 26.744 .200 \\
\hline 3 & 2016 & Maret & 4016 & 39.356 .800 \\
\hline 4 & 2016 & April & 3698 & 36.240 .400 \\
\hline 5 & 2016 & Mei & 4093 & 40.111 .400 \\
\hline 6 & 2016 & Juni & 3850 & 37.730 .000 \\
\hline
\end{tabular}




\begin{tabular}{|c|c|c|c|c|}
\hline 7 & 2016 & Juli & 4309 & 42.228 .200 \\
\hline 8 & 2016 & Agustus & 4225 & 41.405 .000 \\
\hline 9 & 2016 & September & 4111 & 40.287 .800 \\
\hline 10 & 2016 & Oktober & 3636 & 35.632 .800 \\
\hline 11 & 2016 & November & 4191 & 41.071 .800 \\
\hline 12 & 2016 & Desember & 4045 & 39.641 .000 \\
\hline 13 & 2017 & Januari & 3432 & 33.633 .600 \\
\hline 14 & 2017 & Februari & 3809 & 37.328 .200 \\
\hline 15 & 2017 & Maret & 3303 & 32.369 .400 \\
\hline 16 & 2017 & April & 3619 & 35.466 .200 \\
\hline 17 & 2017 & Mei & 3649 & 35.760 .200 \\
\hline 18 & 2017 & Juni & 3836 & 37.592 .800 \\
\hline 19 & 2017 & Juli & 4544 & 44.531 .200 \\
\hline 20 & 2017 & Agustus & 4055 & 39.739 .000 \\
\hline 21 & 2017 & Oktober & 3917 & 38.386 .600 \\
\hline 22 & 2017 & November & 4256 & 41.708 .800 \\
\hline 23 & 2017 & Desember & 5081 & 49.793 .800 \\
\hline 24 & 2018 & Februari & 4306 & 42.198 .800 \\
\hline 25 & 2018 & Maret & 3293 & 32.271 .400 \\
\hline
\end{tabular}

\section{Hasil perhitungan luas atap kampus I}

Daerah tangkapan air hujan yang digunakan terdiri dari atap bangunan Gedung J, K, L dan Gedung M.

Berikut luas daerah tangkapan air hujan

- Gedung M

- Gedung P

- Gedung J

- Gedung L

- Gedung K

- Gedung R

- Gedung Utama
$: 2276 \mathrm{~m}^{2}$
$: 1984 \mathrm{~m}^{2}$
$: 1200 \mathrm{~m}^{2}$
$: 2196 \mathrm{~m}^{2}$
$: 1210 \mathrm{~m}^{2}$
$: 1200 \mathrm{~m}^{2}$
$: 1050 \mathrm{~m}^{2}$

Maka luas atap total adalah $12074 \mathrm{~m}^{2}$ 


\section{Perhitungan volume air hujan yang dapat ditampung}

Tabel 5. Volume Air Hujan yang Dapat Ditampung

\begin{tabular}{|c|c|c|c|c|}
\hline Data & Data Hujan & Periode(tahun) & $\begin{array}{c}\text { Curah } \\
\text { Hujan } \\
(\mathrm{mm})\end{array}$ & $\begin{array}{c}\text { Jumlah } \\
\text { Air yang } \\
\text { dapat } \\
\text { ditampung } \\
\left(\mathbf{m}^{3}\right)\end{array}$ \\
\hline \multirow{3}{*}{ Curah Hujan Rencana } & \multirow{3}{*}{$\begin{array}{c}\text { Stasiun } \\
\text { Meteorologi } \\
\text { Kemayoran }\end{array}$} & 2 & 153,1929 & 1849,6523 \\
\hline & & 5 & 204,6315 & 2470,7268 \\
\hline & & 10 & 238,6884 & 2881,9189 \\
\hline \multirow{2}{*}{$\begin{array}{c}\text { Curah Hujan Harian Rata- } \\
\text { Rata }\end{array}$} & \multirow{2}{*}{\multicolumn{2}{|c|}{$\begin{array}{l}\text { Stasiun Meteorologi Kemayoran } \\
\text { (142 hari hujan dalam } 1 \text { tahun) }\end{array}$}} & 15,266 & 184,3217 \\
\hline & & & $\begin{array}{l}\text { Selama } 1 \\
\text { Bulan }\end{array}$ & 3686,434 \\
\hline
\end{tabular}

Contoh perhitungan:

1. Curah Hujan Rencana (Stasiun Meteorologi Kemayoran Periode 2 Tahun) Jumlah air yang dapat ditampung

$$
\begin{aligned}
& =153,1929 \times 12074 \\
& =1849,6523 \mathrm{~m}^{3} / \text { hari }
\end{aligned}
$$

2. Curah Hujan Harian Rata-Rata (Stasiun Meteorologi Kemayoran)

Jumlah air yang dapat ditampung (1 hari)

$$
\begin{aligned}
& =15,266 \times 12074 \\
& =184,3217 \mathrm{~m}^{3}
\end{aligned}
$$

\begin{tabular}{|c|c|c|}
\hline Atap & $\operatorname{Luas}\left(\mathbf{m}^{2}\right)$ & $\begin{array}{l}\text { Volume Air yang Ditampung } \\
\left(\mathrm{m}^{3}\right)\end{array}$ \\
\hline Gedung M & 2276 & 34,7454 \\
\hline Gedung $\mathrm{P}$ & 1984 & 30,2877 \\
\hline Gedung $\mathrm{R}$ & 1200 & 18,3192 \\
\hline Gedung $\mathbf{J}$ & 2158 & 32,9440 \\
\hline Gedung K & 1210 & 18,4719 \\
\hline Gedung L & 2196 & 33,5241 \\
\hline Gedung Utama & 1050 & 16,0293 \\
\hline Jumlah & 12074 & 184,3217 \\
\hline
\end{tabular}

\section{Perhitungan penampungan air hujan}

Tabel 6. Volume Air Hujan yang Ditampung Setiap Atap 


\section{Perhitungan penghematan tagihan air PAM}

Harga air PAM adalah Rp 9.800,- / $\mathrm{m}^{3}$.

Dari hasil perhitungan jumlah air yang dapat ditampung seperti pada tabel 7, maka didapat penghematan biaya air pada Kampus I Universitas Tarumangara:

\begin{tabular}{|c|c|c|c|c|c|c|}
\hline \multirow[t]{2}{*}{ Data } & \multirow[t]{2}{*}{ Data Hujan } & \multirow[t]{2}{*}{$\begin{array}{l}\text { Periode } \\
\text { (tahun) }\end{array}$} & \multirow[t]{2}{*}{$\begin{array}{c}\text { Curah } \\
\text { Hujan } \\
\text { (mm) }\end{array}$} & \multirow[t]{2}{*}{$\begin{array}{l}\text { Volume Air } \\
\text { Hujan }\left(\mathbf{m}^{3}\right)\end{array}$} & \multicolumn{2}{|c|}{$\begin{array}{l}\text { Penghematan } \\
\text { (Juta Rupiah) }\end{array}$} \\
\hline & & & & & Harian & Tahunan \\
\hline \multirow{3}{*}{$\begin{array}{c}\text { Curah Hujan } \\
\text { Rencana }\end{array}$} & \multirow{3}{*}{$\begin{array}{l}\text { Stasiun } \\
\text { Meteorologi } \\
\text { Kemayoran }\end{array}$} & 2 & 153,19 & 1849,6161 & 18,126 & \multirow{3}{*}{-} \\
\hline & & 5 & 204,63 & 2470,7026 & 24,212 & \\
\hline & & 10 & 238,69 & 2881,9431 & 28,243 & \\
\hline $\begin{array}{c}\text { Curah Hujan } \\
\text { Harian }\end{array}$ & \multicolumn{2}{|c|}{$\begin{array}{l}\text { Stasiun Meteorologi } \\
\text { Kemayoran (142 hari } \\
\text { hujan dalam } 1 \text { tahun) }\end{array}$} & 15,266 & 168,2924 & 1,649 & 234,195 \\
\hline
\end{tabular}

Tabel 7. Penghematan Air

Contoh Perhitungan Stasiun Meteorologi Kemayoran:

$$
\begin{aligned}
\text { Penghematan Per hari } \quad & =1849,6161 \mathrm{~m}^{3} \times \mathrm{Rp} 9800,- \\
& =\mathrm{Rp} 18.126 .237,-
\end{aligned}
$$

Contoh Perhitungan Stasiun Meteorologi Kemayoran:

$$
\begin{aligned}
\text { Penghematan Per Tahun } & =168,2924 \mathrm{~m}^{3} \text { x } 142 \text { hari } \times \mathrm{Rp} 9800,- \\
& =\operatorname{Rp} 234.195 .703,-
\end{aligned}
$$

\section{Perbandingan dengan kebutuhan air menurut SNI 03-7065-2005}

Berdasarkan perhitungan menurut SNI 03-7065-2005, kebutuhan air pada kampus I adalah 622,16 $\mathrm{m}^{3}$ per hari.

Maka penghematan air bersih per hari adalah:

Penghematan air $=168,2924 / 622,16 \times 100 \%$

$$
=27,0497 \%
$$

\section{Perbandingan dengan kebutuhan air menurut data tagihan air}

Berdasarkan perhitungan kebutuhan air menurut data tagihan air, rata-rata pemakaian air per bulan tahun 2016 dan 2017 adalah $3863,6 \mathrm{~m}^{3}$ dan rata-rata pemakaian air per hari $193.18 \mathrm{~m}^{3}$ adalah

Maka penghematan air bersih per hari adalah:

$$
\begin{aligned}
\text { Penghematan air } & =168,2924 / 193,18 \times 100 \% \\
& =87,1169 \%
\end{aligned}
$$

Penghematan uang dalam persen (\%) adalah: 
Total pengeluaran dalam 1 tahun adalah:

(Pengeluaran tahun 2016 + pengeluaran tahun 2017)/2

$=(445.802 .000+468.508 .600) / 2=\operatorname{Rp} 457.155 .300,-$

Jadi total penghematan pengeluaran dalam persen adalah :

$234.195 .703 / 457.155 .300 \times 100 \%=51,2289 \%$

\section{KESIMPULAN}

\section{Kesimpulan}

Dalam skripsi ini dilakukan analisis untuk mengetahui potensi penghematan air dengan diterapkannya Rainwater Harvesting System. Maka dapat ditarik kesimpulan sebagai berikut:

1. Berdasarkan hasil perhitugan, maka didapat curah hujan harian rata-rata sebesar 15,266 pada hari hujan.

2. Berdasarkan perhitungan curah hujan harian rata-rata dan luas area tangkapan sebesar $12074 \mathrm{~m}^{2}$, maka volume air hujan yang dapat ditampung pada 1 hari hujan sebesar $168,2924 \mathrm{~m}^{3}$.

3. Berdasarkan kebutuhan air menurut SNI 03-7065-2005, maka didapat kebutuhan air bersih per hari nya sebesar $622,16 \mathrm{~m}^{3}$. Sementara yang tersedia dari hujan rata-rata adalah $168,2924 \mathrm{~m}^{3}$ air hujan dalam 1 hari. Maka penerapan Rainwater Harvesting dapat menghemat air sebesar 27,0497\% pada hari hujan.

4. Berdasarkan pemakaian air dari data tagihan air tahun 2016 dan 2017, rata-rata pemakaian air per hari adalah $193,18 \mathrm{~m}^{3}$. Sementara yang tersedia dari dari data curah hujan harian rata-rata adalah $168,2924 \mathrm{~m}^{3}$ air hujan dalam 1 hari. Maka penerapan Rainwater Harvesting dapat menghemat air sebanyak 87,1169\% pada hari hujan.

5. Berdasarkan data curah hujan harian rata-rata, dengan volume air hujan yang dapat ditampung per hari sebesar 168,2924 $\mathrm{m}^{3}$ dan dengan harga air PAM adalah $\mathrm{Rp} 9.800$,- per $\mathrm{m}^{3}$, maka biaya air yang dapat dihemat per tahun adalah $\operatorname{Rp} \operatorname{Rp} 234.195 .703$,- dengan perhitungan 142 hari hujan dalam 1 tahun.

\section{Saran}

Berdasarkan hasil analisis, maka disarankan agar dibuat desain lebih rinci beserta perhitungan rencana anggaran biaya (RAB) untuk penerapan Rainwater Harvesting ini di Kampus I Universitas Tarumanagara. Agar hasil lebih akurat, dibutuhkan data curah hujan yang lebih banyak dari pos-pos hujan yang tersebar di sekitar Jabodetabek.

\section{DAFTAR PUSTAKA}

Fathi, Ahmad Saiful, et al. (2014). Perancangan Sistem Rain Water Harvesting, Studi Kasus: Hotel Novotel Yogyakarta. Yogyakarta: Teknofisika, Vol.3 No. 2 Edisi Mei 2014, Issn 2089-7154

Badan Standardisasi Nasional. (2005). SNI 03-7065-2005: Tata Cara Perencanaan Sistem Plambing

Data Online Pusat Database - BMKG, http://dataonline.bmkg.go.id/data_iklim 